\begin{tabular}{|c|c|c|}
\hline BENTHAM OPEN & $\begin{array}{c}\text { The Open Construction and Building } \\
\text { Technology Journal }\end{array}$ & $\begin{array}{l}\text { The Open } \\
\text { Conspruction \& Building } \\
\text { Technology lournal }\end{array}$ \\
\hline CrossMark & $\begin{array}{l}\text { Content list available at: www.benthamopen.com/ТОВCTJ/ } \\
\text { DOI: } 10.2174 / 1874836801610010379\end{array}$ & 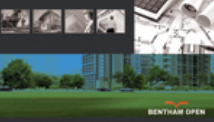 \\
\hline
\end{tabular}

EDITORIAL

\title{
New Trends of Sustainable Materials for Civil Engineering
}

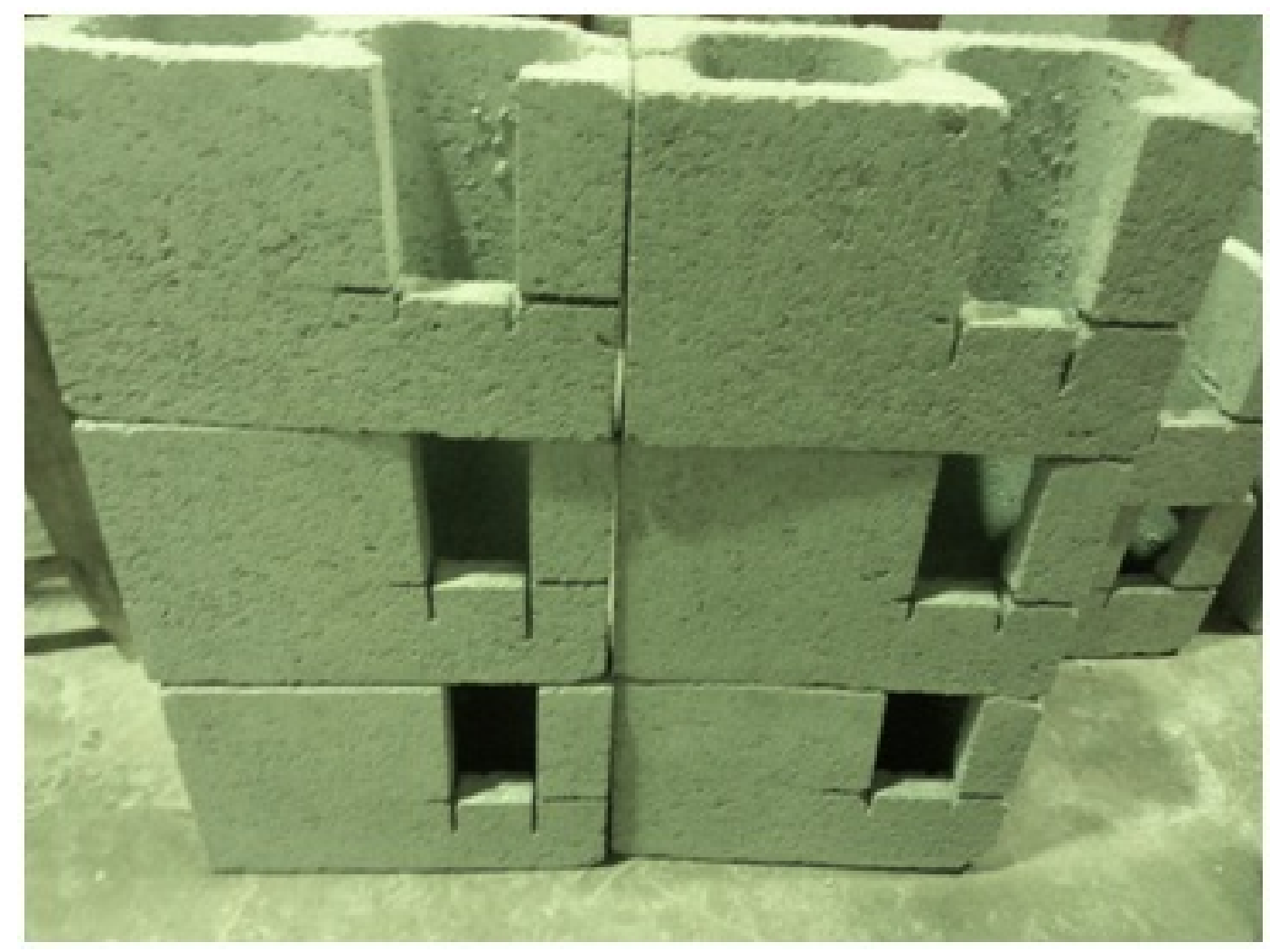

Fig. (1). Sustainable concrete masonry units based on lithium aluminosilicate residue.

The civil engineering industry has recognized the lack of natural resources and the need for sustainable practices and design. Constructing with sustainable materials is not only good for the planet, but it also significantly reduces the production costs, helps preserve our heritage and respond to planning policies. Sustainable materials should not exhaust non-renewable resources and adversely impact the environment. In practice, both these objectives are difficult to achieve, but they rather guide designers, researchers and decision makers. The construction industry constitutes one of the most devastating sectors in terms of environmental impacts, making swift transition from a polluting industry to a more sustainable and environmentally friendly industry. The sustainable construction is achieved, when durable materials, renewable resources, low energy or recyclable alternatives are employed, i.e. the concrete masonry units based on lithium aluminosilicate residue (Fig. 1). Best practices and experiences across sectors and disciplines should be developed in order to optimize the reuse and recycling of eco-efficient materials, as well as to promote cost effective approaches based on scientific knowledge. This special issue on "New Trends of Sustainable Materials for Civil Engineering" has gathered seven publications which contribute to the development of innovative materials and techniques for sustainable construction, such as recycling of industrial wastes, geopolymers, restoration and characterization of fast growth timber beams, and strategies of self-flexible housing. 
Tulio Hallak Panzera

Centre For Innovation and Technology in Composite Materials - CITeC

Federal University of São João del Rei - UFSJ

Praça Frei Orlando, 170

São João del Rei, Minas Gerais

Brazil

Email: panzera@ufsj.edu.br

(C) Tulio Hallak Panzera; Licensee Bentham Open.

This is an open access article licensed under the terms of the Creative Commons Attribution-Non-Commercial 4.0 International Public License (CC BY-NC 4.0) (https://creativecommons.org/licenses/by-nc/4.0/legalcode), which permits unrestricted, non-commercial use, distribution and reproduction in any medium, provided the work is properly cited. 